\title{
Economic Yield and Profitability of Maize/Melon Intercrop as Influenced by Inorganic Fertilizer Application in Humid Forest Ultisol
}

\author{
Kolawole E. LAW-OGBOMO, Peter A. EKUNWE \\ Benson Idahosa University, Department of Agriculture, PMB 1100, Benin City 300001, Nigeria; kolalawogbomo@yahoo.com
}

\begin{abstract}
The trial assessed the viability and profitability of maize and melon production under sole and mixed cropping system on a forest Ultisol. This was conducted as an on-farm trial at Evboneka, Edo State, Nigeria in April 2008 and 2009. The trial involved three cropping patterns (sole maize, sole melon and maize/melon mixture) and four levels of NPK fertilizer (0, 200, 400 and $600 \mathrm{~kg} \mathrm{ha-1})$ in a $3 \times 4$ factorial arrangement in randomized complete block design with three replications. The results revealed that economic yield of maize and melon increased as the fertilizer rate increase. The sole crops had higher yield than in their mixed stands in the entire fertilizer rate. However, land equivalent ratio (LER) values of the mixed crop stands were higher than in their respective sole cropping. The LER was highest (1.47) in maize/melon mixed stands treated with $400 \mathrm{~kg} \mathrm{NPK} \mathrm{ha}^{-1}$. The production cost and economic return followed the same trend as they increased with an increase in fertilizer rate. The sole melon crop had the lowest production cost (\$316.50-588.51) and economic return $(\$ 873-1,305)$ in the entire fertilizer rate compared to the sole maize and maize/melon mixed crop in that order. The net farm income does not follow a definite trend among the three cropping patterns, but the maize/melon intercrop value (\$748.11-997.52) was the highest. The optimum yield was produced from maize $/$ melon mixed stands treated with $200 \mathrm{~kg} \mathrm{ha}^{-1}$. This treatment also gave the highest benefit-cost ratio of 2.19, in addition to ensuring better crop diversity in the rainforest ultisol.
\end{abstract}

Keywords: cropping association, economic yield, land equivalent ratio, NPK fertilizer

\section{Introduction}

The commonest agro-technique by resource-poor farmers in many parts of the tropics is growing of two or more crops on the same field simultaneously (Steiner, 1991). Intercropping or crop mixtures mimic natural ecosystem and are more dynamic biologically than sole crops. Crops grown in mixtures have been found to utilize resources better than sole crops (Chinaka and Obiefuna, 2000). Mixed cropping is done to ensure food security against total crop failure or with intent to maximize yield and profit by making use of the same labour (Yusuf et al., 2008). According to Javanmard et al. (2009), intercropping is popular because of its advantages over sole cropping which include security of returns and higher profitability due to higher combined returns per unit area of land. In addition, crops under intercropping systems are less susceptible to weeds, pests and diseases and minimize erosion through water infiltration control (CTA, 1995).

With high intensity of cropping and shorter fallow periods, decline in soil fertility occurs. This could be ameliorated by adopting a multi-cropping system that has some capacity to help water infiltration into the soil, minimize heat and water losses by evaporation during the day, suppress weeds (Bilalis et al., 2010) and recycle nutrients in order to sustain land productivity (Ogungbaigbe et al., 1990). The use of fast and good cover crop (low growing crops) e.g. melon in particular helps to control erosion.
Maize and melon are some of the farmers' popular crops used for this purpose (Ogungbaigbe et al., 1990). Maize is an important food crop in the tropics and it is well suited to intercropping with short duration crops such as melon based on the fact that the crops are selected on the basis of differences in growth habits and can be combined in either simple or complex mixtures (Ayoola and Makinde, 2007).

LER is an important tool for the study and evaluation of intercropping systems. it is a measure of the yield advantage obtained by growing two or more crops or varieties as an intercrop compared to growing the same crops or varieties as a collection of separate monocultures. LER thus allows us to go beyond a description of the pattern of diversity into an analysis of the advantages of intercropping (Bilalis et al., 2005).

Loss of site productivity on account of bush burning, intensive cropping often without nutrient supplementation, overgrazing, and intense rainfall resulting in leaching and erosion of topsoil are important factors that affect crop productivity in Nigeria (Okonkwo, 1995). Although experimental studies on fertilizer application showed increased crop productivity (Ige et al., 2005), blanket fertilizer recommendations (e.g., 200 to $600 \mathrm{~kg} \mathrm{NPK}$ mixed fertilizer ha-1) (Anonymous, 1987) has obvious limitations. Moreover, crop species and cultivars, besides site characteristics, may vary substantially in their response to fertilizer treatments (Nwinyi and Odurukwe, 1988). Chemical fertilizer is also becoming a major cost fac- 
tor in crop production, and its price has been increasing steadily, besides having potentially undesirable effects on the environment. Hence there is a need to optimize the fertilizer requirement of maize and melon mixtures grown on forest humid ultisol environment sites. Hence maize and melon intercrop in combination with NPK 15:15:15 fertilizer application need to be properly understood so as to fully appreciate the practicability of this combination. This system combines intercropping with the practice of soil fertility maintenance through the use of NPK fertilizer application.

The main objective of this investigation is to evaluate the effect of inorganic fertilizer on the productivity and profitability of maize/melon intercrop.

\section{Materials and methods}

This study was conducted as an on-farm trial at Evboneka, Edo State, Nigeria in April 2008 and 2009. Evboneka is located on latitude $05^{\circ} 45^{\prime} \mathrm{N}$ and longitude $05^{\circ} 45^{\prime} \mathrm{E}$. The soil type is tropical ultisol.

The cultivar of melon used was the Benin local variety obtained from the Edo market in Benin City. The cultivar of maize was 'Downy Mildew Streak Resistance White' ('DMSRW') variety obtained from Agricultural Development Programme (ADP), Benin City. The NPK 15:15:15 fertilizer source was obtained from ADP, Benin City. Treatments consisted of three crop combinations (sole maize, sole melon and maize/melon intercrop and four NPK fertilizer rates $(0(0 \mathrm{~kg} \mathrm{~N}+0 \mathrm{~kg} \mathrm{P}+0 \mathrm{~kg} \mathrm{~K})$, $200(30 \mathrm{~kg} \mathrm{~N}+13.58 \mathrm{~kg} \mathrm{P}+24.90 \mathrm{~kg} \mathrm{~K}), 400(60 \mathrm{~kg} \mathrm{~N}$ $+27.16 \mathrm{~kg} \mathrm{P}+49.80 \mathrm{~kg} \mathrm{~K})$ and $600(90 \mathrm{~kg} \mathrm{~N}+40.74 \mathrm{~kg}$ $\left.\mathrm{P}+74.70 \mathrm{~kg} \mathrm{~K}) \mathrm{kg} \mathrm{ha}^{-1}\right)$. These were laid out in a $3 \times 4$ factorial arrangement in a randomized complete block design of three blocks. Each block consisted of 12 plots, each measuring $4.5 \mathrm{~m} \times 4.0 \mathrm{~m}\left(18 \mathrm{~m}^{2}\right)$ with one meter interplot and inter-block spaces.

Pre-cropping soil samples were collected from the three blocks with an auger drilled at $30 \mathrm{~cm}$ depth and bulked together into a composite for the physical and chemical analysis. The site was manually cleared and ridged with hoes at $0.75 \mathrm{~m}$ apart. Maize and melon were sowed at the same time. Sowing was done as soon as the rain was steady in April in both years. Two seeds were sowed for maize and melon and seedlings later thinned to one plant per stand seven days after sowing. The sole maize and melon plant population stood at 53,333 per hectare. For the intercrop, maize was sown at the base of the ridge at one meter apart to achieve the density of 30,000 plants ha ${ }^{-1}$. Melon was on the crest of the ridge at one meter apart but in between the maize stands to achieve a population of 30,000 plants $\mathrm{ha}^{-1}$.

NPK 15:15:15 fertilizer was applied ten days after sowing by drilling. Two manual weeding were done at three and six weeks after sowing (WAS). Maize was harvested fresh at 12 WAS and sun-dried to $14 \%$ moisture content.
Melon was harvested at 18 WAS. The productivity of the land was measure through land equivalent ratio (LER) was used to assess the economic advantage or otherwise of the maize/melon cropping system over sole crops. It was computed as relative yield (Remison, 1997). The sole maize and melon untreated with fertilizer were maintained as control for the determination of LER.

The LER is calculated using the formula

LER $=\Sigma($ Ypi/Ymi) (Mazaheri and Oveysi, 2004)

where $\mathrm{Yp}$ is the yield of each crop or variety in the intercrop or polyculture, and $\mathrm{Ym}$ is the yield of ach crop or variety in the sole crop or monoculture. For each crop (i) a ratio is calculated to determine the partial LER for that crop, then the partial LERs are summed to give the total LER for the intercrop

Profitability analysis was used to determine the cost and economic return for maize and melon production in the area. The net farm income (NFI) or profit is the difference between total return (TR) and the total cost of production (TC) (Olukosi and Erhabor, 1988).

NFI = TR-TC

The model used for estimating net farm income can be expressed by the equation:

$$
\mathrm{NFI}=\sum_{\mathrm{i}=1}^{\mathrm{n}} \mathrm{P}_{\mathrm{yi}} \mathrm{Y}_{\mathrm{i}}-\sum_{\mathrm{j}=1}^{\mathrm{m}} \mathrm{P}_{\mathrm{xj}} \mathrm{X}_{\mathrm{j}}-\sum_{\mathrm{k}=1}^{\mathrm{k}} \mathrm{F}_{\mathrm{k}}
$$

where NFI $=$ Net farm income

$\mathrm{Yi}=$ Enterprise's product $(\mathrm{s})$ (where $\mathrm{i}=1,2,3, \ldots \mathrm{n}$ products)

$\mathrm{P}_{\mathrm{vi}}=$ Unit price of the product

$X_{j}^{y i}=$ Quantity of the variable inputs (where $j=1,2$, $3, . . \mathrm{m}$ variable inputs)

$\mathrm{F}_{\mathrm{k}}=$ Cost of fixed inputs

$\sum=$ Summation

The total variable cost (TVC) includes items like total cost of labour (land preparation, planting, weeding, fertilizer application and harvesting), fertilizer, planting materials and transportation. The total fixed cost (TFC) includes the cost of renting land and the depreciation of farm implements like cutlasses and hoes.

Analysis of variance was carried out on each year of study, followed by combined analysis over two years using SAS-GLM procedure (SAS Institute, 2004). The Least significant Difference (LSD) test was used for detecting differences between means.

\section{Results and discussion}

The experimental site is characterized by low native soil fertility (Tab. 1) since it contain less than the critical levels of nutrients (Ibedu et al., 1988).

The economic yield of maize and melon were significantly influenced by both intercropping system and NPK fertilizer rates (Tab. 2). Cropping system significantly affected grain yield of maize and seed yield of melon. The yield responses variables showed higher values in sole crops compared to intercrop. Sole crops of maize and mel- 
68

Tab. 1. Soil physical and chemical properties of the experimental site before cropping in both years

\begin{tabular}{ccc}
\hline \multirow{2}{*}{ Soil properties } & \multicolumn{2}{c}{ Crop year } \\
\cline { 2 - 3 } & 2008 & 2009 \\
\hline $\mathrm{pH}\left(\mathrm{H}_{2} \mathrm{O}\right)$ & 5.87 & 6.53 \\
Total Nitrogen $(\%)$ & 0.14 & 0.13 \\
\hline Organic Carbon $(\%)$ & 1.90 & 2.1 \\
Available Phosphorus $\left(\mathrm{mg} \mathrm{kg}^{-1}\right)$ & 4.17 & 2.11 \\
Exchangeable cation $\left(\mathrm{c} \mathrm{mol} \mathrm{kg}^{-1}\right)$ & & \\
\hline $\mathrm{K}$ & 0.07 & 0.09 \\
$\mathrm{Ca}$ & 0.73 & 0.54 \\
$\mathrm{Mg}$ & 0.14 & 0.22 \\
$\mathrm{Na}$ & 0.12 & 0.18 \\
\hline Sand $\left(\mathrm{g} \mathrm{kg}^{-1}\right)$ & 820 & 880 \\
\hline Silt $\left(\mathrm{g} \mathrm{kg}^{-1}\right)$ & 140 & 60 \\
Clay $\left(\mathrm{g} \mathrm{kg}^{-1}\right)$ & 40 & 60 \\
\hline
\end{tabular}

on recorded higher grain $\left(5.02 \mathrm{tha}^{-1}\right)$ and seed $\left(1.12 \mathrm{tha}^{-1}\right)$ of maize and melon, respectively than in their intercrop. This finding agreed with the observation of Olasantan and Lucas (1992) in maize-melon mixtures that the sole crop components yielded higher than the corresponding crops in intercropping situation. This observation is attributed to the fact that sole crop situation take advantage of all the benefits from the agro-ecosystem without competition indicating that the nutrient requirements of maize and melon in the intercropping system were higher than the nutrient need of either crop as sole crop (Mbah et al., 2007). The lower yield observed in the mixed stands could be attributed to competition for growth resources, which was intensified at higher stands associated with the intercropping system.

Maize and melon performed best in terms of economic yields with fertilizer application. Increasing fertilizer rate resulted in higher yield for both the sole and mixed stands. However, the sole crops had higher yield than their counterpart in the mixed stands at the entire fertilizer rates. Maize sole plants treated with $600 \mathrm{~kg} \mathrm{NPK} \mathrm{ha}^{-1}$ had the greatest grain yield $\left(5.53 \mathrm{t} \mathrm{ha}^{-1}\right)$ while melon sole plants treated with $400 \mathrm{~kg} \mathrm{ha}^{-1}$ had greatest seed yield of $1.12 \mathrm{t}$ $\mathrm{ha}^{-1}$. This is an indication of the efficiency of higher productivity through fertilizer application. This position was earlier reported by Opara (1992), Ehigiator (1998) and Egharevba and Ogbe (2002). The untreated stands in both sole cropping and mixed cropping systems had the least for their respective crops as they had to depend mainly on the intrinsic soil fertility as exhibited by the soil chemical analysis to be low. Therefore, it was not surprising that yields would be low in poor soils. Padwick (1983) has observed that many tropical soils showed nutrient deficiency problems and a decrease in crop yields after only a short period of cultivation.

The results of the intercropping system indicated that LER of the mixed crops was higher than the pure stand crops (Tab. 3) indicating a greater productivity per unit area of land for the mixtures than when either of the crops are grown separately (Wiley, 1990). These higher values revealed complementation in resource utilization by the component crops and that the land resource was efficiently utilized. The mean LER values increased with an increase in

Tab. 2. Economic yield $\left(\mathrm{t} \mathrm{ha}^{-1}\right)$ as influenced by intercropping and NPK fertilizer application

\begin{tabular}{|c|c|c|c|c|c|c|c|c|c|c|}
\hline \multirow{3}{*}{ Crop combination } & \multicolumn{5}{|c|}{ Maize (grain t ha ${ }^{-1}$ ) } & \multicolumn{5}{|c|}{ Melon $\left(\right.$ seed $\left.\mathrm{t} \mathrm{ha}^{-1}\right)$} \\
\hline & \multicolumn{5}{|c|}{ Fertilizer application rate $\left(\mathrm{kg} \mathrm{ha}^{-1}\right)$} & \multicolumn{5}{|c|}{ Fertilizer application rate $\left(\mathrm{kg} \mathrm{ha}^{-1}\right)$} \\
\hline & 0 & 200 & 400 & 600 & Mean & 0 & 200 & 400 & 600 & Mean \\
\hline Sole maize & 4.53 & 4.82 & 5.20 & 5.53 & 5.02 & 0.00 & 0.00 & 0.00 & 0.00 & 0.00 \\
\hline Sole melon & 0.00 & 0.00 & 0.00 & 0.00 & 0.00 & 0.97 & 1.03 & 1.45 & 1.02 & 1.12 \\
\hline Maize/melon intercrop & 2.23 & 3.06 & 3.08 & 3.29 & 2.92 & 0.62 & 0.73 & 0.76 & 0.71 & 0.71 \\
\hline Mean & 3.38 & 3.94 & 4.14 & 4.41 & 3.97 & 0.80 & 0.88 & 1.11 & 0.87 & 0.92 \\
\hline $\operatorname{LSD}(\mathrm{P}=0.05) \mathrm{CP}$ & & & & & 1.453 & & & & & 1.453 \\
\hline $\operatorname{LSD}(\mathrm{P}=0.05)$ Fertilizer & & & & & 0.436 & & & & & 0.436 \\
\hline $\operatorname{LSD}(\mathrm{P}=0.05) \mathrm{CP} \times \mathrm{Fr}$ & & & & & ns & & & & & ns \\
\hline
\end{tabular}

ns-not significant. CP-crop combination Fr.-fertilizer rate

Tab. 3. LER as influenced by intercropping and fertilizer application

\begin{tabular}{|c|c|c|c|c|c|c|c|c|c|c|c|c|c|c|c|}
\hline \multirow{3}{*}{ Cropping system } & \multicolumn{5}{|c|}{ Maize } & \multicolumn{5}{|c|}{ Melon } & \multicolumn{5}{|c|}{ Total } \\
\hline & \multicolumn{5}{|c|}{ Fertilizer application rate $\left(\mathrm{kg} \mathrm{ha}^{-1}\right)$} & \multicolumn{5}{|c|}{ Fertilizer application rate $\left(\mathrm{kg} \mathrm{ha}^{-1}\right)$} & \multicolumn{5}{|c|}{ Fertilizer application rate $\left(\mathrm{kg} \mathrm{ha}^{-1}\right)$} \\
\hline & 0 & 200 & 400 & 600 & Mean & 0 & 200 & 400 & 600 & Mean & 0 & 200 & 400 & 600 & Mean \\
\hline Sole Maize & 1.00 & 1.08 & 1.15 & 1.22 & 1.11 & 0.00 & 0.00 & 0.00 & 0.00 & 0.00 & 1.00 & 1.06 & 1.15 & 1.22 & 1.11 \\
\hline Sole Melon & 0.00 & 0.00 & 0.00 & 0.00 & 0.00 & 1.00 & 1.06 & 1.52 & 1.05 & 1.10 & 1.00 & 1.06 & 1.52 & 1.05 & 1.10 \\
\hline Maize/melon mixture & 0.49 & 0.68 & 0.69 & 0.73 & 0.65 & 0.64 & 0.75 & 0.78 & 0.73 & 0.73 & 1.11 & 1.43 & 1.47 & 1.46 & 1.37 \\
\hline Mean & 0.50 & 0.59 & 0.61 & 0.65 & 0.59 & 0.55 & 0.60 & 0.77 & 0.59 & 0.61 & 1.04 & 1.18 & 1.38 & 1.24 & 1.21 \\
\hline $\operatorname{LSD}(\mathrm{P}=0.05) \mathrm{CP}$ & & & & & 0.065 & & & & & 0.048 & & & & & 0.987 \\
\hline $\operatorname{LSD}(\mathrm{P}=0.05)$ Fertilizer & & & & & 0.567 & & & & & 0.068 & & & & & 0.115 \\
\hline $\operatorname{LSD}(\mathrm{P}=0.05) \mathrm{CP} \times \mathrm{Fr}$ & & & & & ns & & & & & ns & & & & & ns \\
\hline
\end{tabular}

ns-not significant. CP-crop combination, Fr-fertilizer rate 
Tab. 4. Profitability analysis of maize and melon from sole maize/melon mixed cropping systems

\begin{tabular}{|c|c|c|c|c|c|c|c|c|c|c|c|c|}
\hline \multirow{3}{*}{$\begin{array}{c}\text { Items of cost and } \\
\text { return }(\$)\end{array}$} & \multicolumn{4}{|c|}{ Maize } & \multicolumn{4}{|c|}{ Melon } & \multicolumn{4}{|c|}{ Maize/melon } \\
\hline & \multicolumn{4}{|c|}{ Fertilizer application rate $\left(\mathrm{kg} \mathrm{ha}^{-1}\right)$} & \multicolumn{4}{|c|}{ Fertilizer application rate $\left(\mathrm{kg} \mathrm{ha}^{-1}\right)$} & \multicolumn{4}{|c|}{ Fertilizer application rate $\left(\mathrm{kg} \mathrm{ha}^{-1}\right)$} \\
\hline & 0 & 200 & 400 & 600 & 0 & 200 & 400 & 600 & 0 & 200 & 400 & 600 \\
\hline Land preparation & 172.41 & 172.41 & 172.41 & 172.41 & 172.41 & 172.41 & 172.41 & 172.41 & 172.41 & 172.41 & 172.41 & 172.41 \\
\hline Fertilizer (NPK) & 0.00 & 69.24 & 143.45 & 215.17 & 0.00 & 69.24 & 143.45 & 215.17 & 0.00 & 69.24 & 143.45 & 215.17 \\
\hline Planting material & 9.10 & 9.10 & 9.10 & 9.10 & 8.40 & 8.40 & 8.40 & 8.40 & 11.67 & 11.67 & 11.67 & 11.67 \\
\hline Transport & 15.62 & 20.31 & 31.32 & 43.10 & 7.81 & 10.26 & 15.66 & & 17.86 & 23.67 & 33.13 & 43.10 \\
\hline Planting & 16.24 & 16.24 & 16.24 & 16.24 & 12.18 & 12.18 & 12.18 & 12.18 & 18.95 & 18.95 & 18.95 & 18.95 \\
\hline Weeding & 86.20 & 86.20 & 86.20 & 86.20 & 43.10 & 43.10 & 43.10 & 43.10 & 76.20 & 76.20 & 76.20 & 76.20 \\
\hline Fertilizer application & 0.00 & 10.34 & 20.53 & 43.17 & 0.00 & 10.34 & 20.53 & 43.17 & 0.00 & 10.34 & 20.53 & 43.17 \\
\hline Harvesting & 43.10 & 43.10 & 43.10 & 43.10 & 43.10 & 43.10 & 43.10 & 43.10 & 43.10 & 43.10 & 43.10 & 43.10 \\
\hline Renting & 17.24 & 17.24 & 17.24 & 17.24 & 17.24 & 17.24 & 17.24 & 17.24 & 17.24 & 17.24 & 17.24 & 17.24 \\
\hline Depreciation & 12.26 & 12.26 & 12.26 & 12.26 & 12.26 & 12.26 & 12.26 & 12.26 & 12.26 & 12.26 & 12.26 & 12.26 \\
\hline Total cost of production & 372.17 & 456.44 & 551.85 & 657.99 & 316.50 & 398.53 & 488.33 & 588.51 & 369.69 & 455.08 & 548.94 & 653.20 \\
\hline Revenue & 1177.80 & 1253.20 & 1352.00 & 1437.80 & 873.00 & 1030.90 & 1305.00 & 918.00 & 1117.80 & 1452.60 & 1484.80 & 1494.40 \\
\hline Net farm income & 805.63 & 796.76 & 800.15 & 779.81 & 556.50 & 632.37 & 816.67 & 329.49 & 748.11 & 997.52 & 935.86 & 841.20 \\
\hline Benefit-cost ratio & 2.16 & 1.74 & 1.45 & 1.19 & 1.76 & 1.59 & 1.67 & 0.56 & 2.02 & 2.19 & 1.70 & 1.29 \\
\hline
\end{tabular}

fertilizer rate from 0 to $600 \mathrm{~kg} \mathrm{ha}^{-1}$ for both sole maize and intercropped maize but for sole melon and intercropped melon, it increased up to $400 \mathrm{~kg} \mathrm{NPK} \mathrm{ha}{ }^{-1}$ and declined at $600 \mathrm{~kg} \mathrm{NPK} \mathrm{ha}^{-1}$ (Tab. 3). This is an indication of positive responses of the crops to fertilizer application through which performance is enhanced as it supplements nutrients in the soil. The LER values of 1.22 for sole maize and 1.52 for sole melon are indications of efficiency and high productivity through the use of inorganic fertilizer. There was yield disadvantage of the component crop as they all indicated values below one but the total of the mixtures were more than their pure stands. The highest LER of 1.47 was obtained from the combination of maize/melon intercrop and $400 \mathrm{~kg} \mathrm{NPK} \mathrm{ha}^{-1}$.

The total cost of production, economic return, net farm income and benefit-cost ratio of maize and melon was influenced by the cropping systems and NPK fertilizer rate (Tab. 4). The highest cost was observed in the production of maize from the sole cropping while the least was observed in the production of melon from the sole cropping system. However, the cost increased as the fertilizer rate increased in all the cropping systems. In this study, economic return (\$1494.40) was the highest in maize/melon mixture treated with $600 \mathrm{~kg} \mathrm{NPK} \mathrm{ha}{ }^{-1}$. The maize/melon intercrop had higher values than the pure stand crops. The values increased with increase in fertilizer rate up to maximum quantity applied. The net farm income was highest for the intercrop than the sole crops in both seasons. It was highest (\$997.52) with the maize/ melon intercrop treated with $200 \mathrm{~kg} \mathrm{ha}^{-1}$, followed by the maize/melon intercrop treated with $400 \mathrm{~kg} \mathrm{NPK} \mathrm{ha}^{-1}$ with a value of \$ 935 and the least was $\$ 329.49$ obtained from the sole melon crops treated with $600 \mathrm{~kg} \mathrm{NPK} \mathrm{ha}{ }^{-1}$. The trend exhibited by the three cropping systems to fertilizer rate was not the same. The net farm income declined as the fertilizer rate increased while in the mixed crops it increased up to a peak and declined thereafter in a succes- sive manner. This was contrary to economic return. This implied that the less benefit was accrued to the additional cost incurred as a result of fertilizer application and that the farmers would earn highest benefit growing maize/ melon intercrop treated with $200 \mathrm{~kg} \mathrm{NPK} \mathrm{ha-1}$.

Benefit-cost ratio was higher in maize/melon intercrop and lower in both sole crops. The benefit-cost ratio which serves as economic index for evaluating the profitability and viability of an enterprise, however, followed a different trend. It was highest under sole crops of maize (2.16) and melon (1.76) without any fertilizer treatment and declined with increasing fertilizer rates. This implies that for every \$ 1.00 spent a return of $\$ 2.16$ and $\$ 1.76$ was obtained for maize and melon respectively. The benefit-cost ratio of the intercrop however followed a different trend with a peak (2.19) at $200 \mathrm{~kg} \mathrm{NPK} \mathrm{ha}^{-1}$ and a decline thereafter.

The major inference that could be deduced from this trial is that intercropping maize with melon is highly profitable with increased yield, higher net farm income and benefit-cost ratio. Intercropping system has resulted in greater viability in annual returns compared with sole cropping. This is contrary to the view of Yusuf et al. (2008), who reported that intercropping resulted in less viability in annual returns compared with sole cropping. The average farmer in the tropic has been showed to be highly rational and would therefore not spend all of his most scare resources on the production of single crop alone but on combination of crops due to better utilization of land, labour and capital. This agreed with Seran and Brintha (2009) who reported that intercropping occupies greater land use and thereby provides higher net returns.

\section{Conclusions}

It has been shown in this trial that farmers in the tropic would maximize their earning by practicing intercropping rather than sole cropping. The economic indices of 
70

viability and profitability show that the farmer would obtain optimum economic returns from maize/melon intercrop treated with $200 \mathrm{~kg}$ NPK 15:15:15 ha ${ }^{-1}$. Farmers would however need to be assisted with necessary inputs and extension services to enable them actualize the aim of maximizing their earning. The farmers' economic base, increased food security and assured availability of maize and melon.

\section{References}

Anonymous (1987). Fertilizer use in crops. Bendel State Agricultural Development Programme, Benin City, Nigeria. $6 \mathrm{p}$.

Ayoola OT, Makinde EA (2007). Fertilizer treatment effects on performance of cassava under two planting patterns in a cassava-based cropping system in South West Nigeria. Res J Agric Biol Sci 3(1):13-20.

Bilalis D, Papastylianou P, Konstantas A, Patsiali S, Karkanis A, Efthimiadou A (2010). Weed-suppressive effects of maizelegume intercropping in organic farming. Int J Pest Mgt 56(2):173-181.

Bilalis D, Sidiras N, Kakampouki I, Efthimiadou A, Papatheohari Y, Thomopoulos P (2005). Effects of organic fertilization on maize/legume intercrop in a clay loam soil and Mediterranean climate- Can the Land Equivalent Ratio (LER) index be used for root development? J Food Agri Environ 3:117-123.

Chinaka CC, Obiefuna JC (2000). Evaluation of optimum population and biological efficiency of sweet potato/maize intercropping system. Nigerian Agric J 31:158-165.

CTA (1995). Centre for Tropical Agriculture. Farming System Research. Spore Bull 56:1-5.

Egharevba RKA, Ogbe FM (2002). The effects of different levels of organic and mineral fertilizers on the yield performance of two Amaranthus (A. cruentus) cultivars. The Plant Sci 3:62-72.

Ehigiator JO (1998). Farmyard manure for its adoption as an alternative to chemical fertilizer uses. Nigerian J Hort Sci 3:1-9.

Ibedu MA, Unambra RPA, Udealor A (1988). Soil management strategies in relation to farming system development in the south eastern agricultural zone of Nigeria. Paper presented at the National Farming system Research Workshop, Jos, Plateau State, Nigeria, 26-29 p.

Ige DW, Adepetu JA, Obi OA (2005). Effect of organic amendment on $\mathrm{P}$ release in soils of south western Nigeria. Ife J Agric 1:1-70.

Javanmard A, Mohammadi-Nasab AD, Javanshir A, Moghaddam M, Janmohammadi H (2009). Forage yield and quality in intercropping of maize with different legumes as doublecropped. J Food, Agric Environ 7(1):163-166.
Mazaheri D, Oveysi M (2004). Effects of intercropping of two corn varieties at various nitrogen levels. Iranian J Agron 71$76 \mathrm{pp}$.

Mbah EU, Muoneke CO, Okpara DA (2007). Effects of compound fertilizer on the yield and productivity of soybean and maize in soyabean/maize intertcrop in southeastern Nigeria. Trop Subtrop System 7:87-95.

Nwinyi SCO, Odurukwe SO (1988). Optimum NPK requirement of white yam (Dioscorea rotundata). Nig Agric J 24:63-70.

Ogungbaigbe L, Eniola I, Akanbi AS (1990). Comparative effects of intercropping melon, cowpea and sweet potatoes with maize in southwestern Nigeria. Horticultural Society of Nigeria (HORTON) conference proceeding, Ibadan, 56$58 \mathrm{p}$.

Okonkwo SNC (1995). Effect of pre-sprouting and planting depth of yam (Dioscorea spp) minisett on field establishment, tuber yield and net income in the southern Guinea savanna of Nigeria. Nig Agric J 28:1-8.

Olasantan FO, Lucas EO (1992). Intercropping maize with crops of differing canopy heights and similar or different maturities using different spatial arrangements. J Agricult Sci Technol 2:12-22.

Olukosi JO, Erhabor PO (1988). Introduction to farm management-economic; principles and application AGITAB. Publisher, Zaria, Nigeria, 48-56 p.

Opara CN (1992). Aspects of morphology and fruiting characteristics of Solanum varieties and their responses to poultry manure and irrigation. MSc Thesis UNN $222 \mathrm{p}$.

Padwick GW (1983). Fifty years of experiment II. The maintenance of soil fertity in tropical Africa. A review. Experim Agricult 19:293-310.

Remison SU (1997). Basic principles of crop physiology. Sadoh Press (Nig.), Benin City, 163 p.

SAS Institute (2004). SAS user's guide. Statistic, version 9.0. Statistic Institute Inc. Cary, North Carolina, USA.

Seran TH, Brintha I (2009). Study on biological and economic efficiency of Radish (Raphanus sativus L.) intercrop with vegetable Amaranthus (Amaranthus bicolor L.). Open Hortis J 12:17-21.

Steiner KG (1991). Overcoming soil fertility constraints to crop production in West Africa: Impact of traditional and improved cropping systems on soil fertilizer, p. 69-91. In: Mokwunye AU (Ed.). Alleviating soil fertility constraints to increased crop production in West Africa.

Wiley RW (1990). Resource use in intercropping systems. Agricult Water Manage 17:215-231

Yusuf O, Sanni SA, Ojuekaiye EO, Ugbabe OO (2008). Profitability of 'egusi' melon (Critrullus lanatus Thunb. Mansf) production under sole and mixed cropping systems in Kogi State, Nigeria. ARPN J Agric Biol Sci 3:14-18. 